\title{
FDA- and EMA-Approved Tyrosine Kinase Inhibitors in Advanced EGFR-Mutated Non-Small Cell Lung Cancer: Safety, Tolerability, Plasma Concentration Monitoring, and Management
}

\author{
Isabelle Solassol ${ }^{1,2, *}$, Frédéric Pinguet ${ }^{2}$ and Xavier Quantin ${ }^{3}$ \\ 1 Unité de Recherche Translationnelle, Institut du Cancer de Montpellier (ICM), 34000 Montpellier, France \\ 2 Département de Pharmacie, Institut du Cancer de Montpellier (ICM), 34000 Montpellier, France; \\ frederic.pinguet@icm.unicancer.fr \\ 3 Service d'Oncologie Médicale, Institut du Cancer de Montpellier (ICM), IRCM, INSERM, Univ. Montpellier, \\ 34000 Montpellier, France; xavier.quantin@icm.unicancer.fr \\ * Correspondence: Isabelle.solassol@icm.unicancer.fr; Tel.: +00-3346-7613-722
}

Received: 8 October 2019; Accepted: 25 October 2019; Published: 30 October 2019

check for updates

\begin{abstract}
Non-small-cell lung cancer (NSCLC) is the most common form of primary lung cancer. The discovery of several oncogenic driver mutations in patients with NSCLC has allowed the development of personalized treatments based on these specific molecular alterations, in particular in the tyrosine kinase (TK) domain of the epidermal growth factor receptor (EGFR) gene. Gefitinib, erlotinib, afatinib, and osimertinib are TK inhibitors (TKIs) that specifically target EGFR and are currently approved by the Food and Drug Administration (FDA) and the European Medicines Agency (EMA) as first line treatment for sensitive EGFR-mutant patients. However, these four drugs are associated with severe adverse events (AEs) that can significantly impact patient health-related quality of life and patient monitoring. EGFR-TKIs are commonly used together with other types of medication that can substantially interact. Here, we review approaches used for the management of TKI-AEs in patients with advanced NSCLC to promote the benefits of treatments and minimize the risk of TKI treatment discontinuation. We also consider potential TKI-drug interactions and discuss the usefulness of plasma concentration monitoring TKIs based on chromatographic and mass spectrometry approaches to guide clinical decision-making. Adjusting the most appropriate therapeutic strategies and drug doses may improve the performance therapy and prognosis of patients with advanced EGFR-mutated NSCLC.
\end{abstract}

Keywords: TKIs; NSCLC; side effects; TDM; quantification

\section{Introduction}

Non-small-cell lung cancer (NSCLC) accounts for more than $80 \%$ of lung cancer cases, with the majority of patients presenting with advanced disease at the time of diagnosis [1]. Advances in targeted and individualized treatment of NSCLC since the late 2000s have led to the development of epidermal growth factor receptor (EGFR)-tyrosine kinase inhibitors (TKIs), such as first-generation reversible gefitinib (Iressa) [2] and erlotinib (Tarceva) [3], and second-generation irreversible afatinib (Giotrif) [4]. These U.S. Food and Drug Administration (FDA)-approved drugs exhibit higher efficacy in patients harboring specific activating molecular alterations in the tyrosine kinase domain of EGFR (exons 18-21). Among them, the most common EGFR-activating mutations are exon 19 deletions (del19) (45\%) and the L858R exon 21 substitution (40-45\%) [5]. Exon 18 mutations occur much less frequently, accounting for approximately $5 \%$ of EGFR mutations. 
Unfortunately, the response to first- and second-generation EGFR-TKIs is severely impaired in almost all patients by the unavoidable emergence of resistance to targeted therapy within 10-12 months. Several mechanisms of acquired resistance have been identified, but the secondary missense T790M mutation in cis with a primary activating mutant EGFR allele is over-represented and has been reported in more than half of all cases [6]. The T790M mutation is a gatekeeper mutation located in the ATP-binding pocket that increases the affinity of EGFR for ATP. However, besides first-generation EGFR-TKIs, second-generation EGFR-TKIs have also failed to overcome T790M-mediated resistance because the concentrations at which these drugs overcome T790M activity preclinically are too toxic and cannot be achieved in patients $[7,8]$.

A third generation of irreversible EGFR-TKIs, such as osimertinib (Tagrisso) [9], has been developed to overcome acquired EGFR-TKI resistance due to EGFR-T790M mutation. The development of this treatment strategy, in contrast to first- and second-generation EGFR-TKIs that act on the central nervous system, has markedly improved both the clinical management and outcome of patients with advanced NSCLC [10]. Osimertinib has been demonstrated to be more efficient than conventional EGFR-TKIs and has been rapidly approved as a first-line treatment of advanced EGFR-mutated NSCLC [11]. Unfortunately, these compounds are also associated with the development of tumoral clone resistance after 6-17 months of therapy [12].

Most patients treated with EGFR-TKIs develop relatively controlled toxicity. However, only a small proportion discontinue EGFR-TKI therapy due to the appearance of significant and disabling adverse events (AEs) that impact quality of life $[13,14]$. These effects include dermatological reactions, diarrhea, hepatotoxicity, stomatitis, interstitial lung disease, and ocular toxicity [15]. Switching EGFR-TKIs, reducing doses, or discontinuing EGFR-TKIs temporarily before the patient develops severe AEs, notably hepatotoxicity, improves the performance of the drug and prognosis of patients with positive EGFR-mutated tumors [16]. Clinical practice can also involve the implementation of appropriate supportive care measures. To avoid AEs and control interindividual pharmacokinetic variations, drug doses should ideally be adapted for each patient, not according to body surface area as usual for chemotherapy, but rather according to blood concentrations of the drug. Therapeutic drug monitoring (TDM), based on the blood dosage of a drug, is a useful tool for providing individual treatment adapted by dose adjustment. In this review, we focus on the pharmacokinetic (PK) data and known drug interactions for each of the currently available EGFR-TKIs. We summarize the most severe adverse effects observed with first-, second-, and third-generation EGFR-TKIs. We provide an overview of analytical methods used for TDM and recent clinical trials on exposure response relationships of these novel agents. Finally, we discuss the role of oncologists in safely managing EGFR-TKIs use to ensure maximum patient benefit.

\section{Currently Approved EGFR-TKIs}

\subsection{Erlotinib}

Erlotinib is a low molecular weight, reversible, and oral competitive inhibitor of EGFR tyrosine kinase that inhibits intracellular phosphorylation of EGFR. In EGFR mutation-positive tumors, erlotinib binds tightly to the ATP-binding site in the mutated kinase domain, which results in potent blocking of the MAP-kinase signaling. The blocking of signaling results in the interruption of tumoral cell proliferation and the activation of the intrinsic apoptosis pathway [17].

Erlotinib was the first EGFR-TKI assessed in the first-line treatment of locally advanced or metastatic NSCLC patients with EGFR activating mutations, and compared to standard chemotherapy [17]. Based on the positive results of the multicentric EURTAC trial, erlotinib was approved in 2013 for first-line therapy in advanced NSCLC in patients with del19 or the L858R substitution [18]. Erlotinib possesses several specific pharmacokinetic parameters as detailed in Table 1. If simultaneously administered with food, erlotinib must be administered during fasting because its absorption can be thus modified, delaying gastric emptying and its bioavailability [17]. The recommended dose of erlotinib is $150 \mathrm{mg}$ 
daily, which can be administered either one hour before a meal (complete fasting) or two hours after a meal $[19,20]$. Erlotinib is rapidly absorbed and has a poor bioavailability and a long half-life (>36 h) [21]. Erlotinib is mainly metabolized by CYP3A4 in the liver. Erlotinib is also, but less extensively, metabolized by the CYP1A2, CYP1A1, and CYP1B1 enzymes through demethylation of side chains $[22,23]$.

Table 1. Summary of steady-state pharmacokinetics of 4 TKI after multiple once daily oral doses.

\begin{tabular}{|c|c|c|c|c|}
\hline Parameter and unit & Erlotinib & Gefetinib & Afatinib & Osimertinib \\
\hline $\begin{array}{l}\text { Usual starting dose } \\
\text { (mg) }\end{array}$ & 150 & 250 & 40 & 80 \\
\hline $\mathrm{AUC}_{\tau, \mathrm{ss}}$ & 27 (ng h/mL) & 258 (ng h/mL) & $631(\mathrm{ng} \mathrm{h} / \mathrm{mL})$ & 9570 (nmol h/L) \\
\hline $\mathrm{C}_{\max , \mathrm{ss}}$ & 1521 (ng/mL) & 101(ng/mL) & $38.0(\mathrm{ng} / \mathrm{mL})$ & $550.4(\mathrm{nmol} / \mathrm{L})$ \\
\hline$t_{\max , s s}(h)$ & 4 & 4 & 3 & 4 \\
\hline $\mathrm{t}_{1 / 2 \text {,ss }}(\mathrm{h})$ & 36 & 52 & 37 & 48.6 \\
\hline $\mathrm{CL} / \mathrm{F}_{\mathrm{SS}}(\mathrm{L} / \mathrm{h})$ & 4.5 & 46 & 1070 & 17.7 \\
\hline $\mathrm{V}_{\mathrm{z}} / \mathrm{F}_{\mathrm{SS}}(\mathrm{L})$ & 232 & 1700 & 2870 & 1216 \\
\hline Protein binding $(\%)$ & 95 & 90 & 95 & NA \\
\hline
\end{tabular}

Abbreviations: $\mathrm{AUC}_{\tau}$, ss area under the drug plasma concentration-time curve at steady state over a uniform dosing interval $\tau, \mathrm{CL} / \mathrm{Fss}$ clearance of drug from plasma after oral administration at steady state, Cmax,ss maximum drug concentration in plasma at steady state, ss steady state, $\mathrm{t}$,ss terminal elimination half-life at steady state, tmax,ss time to reach Cmax,ss, Vz/Fss (apparent) volume of distribution at steady state.

Since patients undergoing cancer treatment frequently use acid-reducing agents (ARAs), such as proton pump inhibitors (PPIs), H2-receptor antagonists (H2RAs), and antacids for palliation of dyspepsia, gastroesophageal reflux disease, or gastritis, erlotinib PK exposure has been widely assessed. The erlotinib PK values are significantly reduced upon concomitant administration with omeprazole, a PPI, and ranitidine, an H2RA, but not when administered with a staggered dosing approach to ranitidine. Therefore, concomitant use of erlotinib with PPI or H2RAs is not recommended in clinical practice. If treatment with an H2RA is required, erlotinib should be administered $10 \mathrm{~h}$ after the H2RA dosing and at least two hours before the next antagonist drug administration [24]. Kletzl et al. reported, in a retrospective study of 157 EGFR-mutated advanced NSCLC patients treated with erlotinib or gefitinib, that co-administration of acid-suppressant therapy did not significantly affect the efficacy (overall response rate (ORR) and progression-free survival (PFS)) in the overall cohort [24]. Finally, gastroesophageal reflux disease should clinically managed with the prescription of sucralfate and the limitation of gastric irritants and acid-rich foods.

Erlotinib exposure may be affected by concomitant use of other drugs that act on CYP3A4/1A1/1A2/1B1 and may result in re-distribution and changes in intracellular/tumor cell drug concentrations (Table 2). Thus, erlotinib should be used with caution with CYP3A4 inducers and inhibitors such as antifungal (e.g., ketoconazole), antibiotic (e.g., rifampicin), and antiretroviral drugs with an adaptation of the standard dose [25-27].

Finally, cigarette smoking has been shown to accelerate erlotinib catabolism, which is particularly important in the population of lung cancer patients. The plasma levels of erlotinib measured in current smokers almost doubled compared with those of former smokers and non-smokers $24 \mathrm{~h}$ after dosing [28]. Hamilton et al. compared the pharmacokinetic variables of erlotinib in current smokers and reported that an increased dose of erlotinib may benefit these patients [29]. Subsequent studies in patients with NSCLC confirmed this observation $[17,30]$. Therefore, the most crucial intervention is smoking cessation. Otherwise, increasing the dose of erlotinib by $50 \mathrm{mg}$ is recommended at two-week intervals up to a maximum of $300 \mathrm{mg}$ per day for concomitantly cigarette smoking patients. 
Table 2. Oral agents for treatment and significant interactions of metastatic lung cancer.

\begin{tabular}{|c|c|c|c|c|}
\hline TKIs & $\begin{array}{l}\text { Recommended } \\
\text { Dosage/Day }\end{array}$ & Indication & Common AEs & Drug-Drug Interactions \\
\hline Erlotinib & $\begin{array}{l}150 \mathrm{mg} 1 \mathrm{~h} \text { before } \\
\text { or } 2 \mathrm{~h} \text { after food }\end{array}$ & $\begin{array}{c}\text { first-line for } \\
\text { advanced NSCLC }\end{array}$ & $\begin{array}{l}\text { rash, diarrhea, edema, } \\
\text { cough, conjunctivitis }\end{array}$ & $\begin{array}{l}\text { inducer of CYP1A2 inhibitor of } \\
\text { CYP3A4, CYP1A1 and CYP2C8, } \\
\text { medication that alter gastric pH }\end{array}$ \\
\hline Gefitinib & $250 \mathrm{mg}+/-$ food & $\begin{array}{c}\text { first-line for } \\
\text { advanced NSCLC }\end{array}$ & $\begin{array}{l}\text { skin reaction, rash, } \\
\text { anorexia, stomatitis } \\
\text { diarrhea, paronychia }\end{array}$ & $\begin{array}{c}\text { inducers of CYP3A4, and CYP2D6, } \\
\text { P-gp, inhibitors of CYP2C19 and } \\
\text { CYP2D6, UGT1A1, medication } \\
\text { that alter gastric pH }\end{array}$ \\
\hline Afatinib & $\begin{array}{l}40 \mathrm{mg} 1 \mathrm{~h} \text { before or } \\
2 \mathrm{~h} \text { after food }\end{array}$ & $\begin{array}{l}\text { second-line for } \\
\text { advanced NSCLC }\end{array}$ & $\begin{array}{l}\text { eruption rash dry ski, } \\
\text { diarrhea, loss of } \\
\text { appetite, stomatitis } \\
\text { diarrhea, rash, dry }\end{array}$ & $\begin{array}{l}\text { negligible metabolism via CYP } \\
\text { pathways; substrate and potential } \\
\text { inhibitor of P-gp }\end{array}$ \\
\hline Osimertinib & $80 \mathrm{mg}+/-$ food & $\begin{array}{l}\text { third-line for } \\
\text { advanced NSCLC }\end{array}$ & $\begin{array}{l}\text { skin, nail toxicity, ILD, } \\
\text { QTc prolongation, } \\
\text { ocular desorder } \\
\text { cardiomyopathy }\end{array}$ & inducers of CYP3A \\
\hline
\end{tabular}

Abbreviations: QTc, QT interval corrected for heart rate, ILD Interstitial lung disease, CYP cytochrome P450, UGT, uridine diphosphate-glucuronosyltransferase, P-gp P-glycoprotein, +/- food with or without food, AEs adverse events, NSCLC non-small cell lung cancer.

\subsection{Gefitinib}

Gefitinib is a drug that inhibits EGFR tyrosine kinase by targeting the ATP cleft within EGFR to prevent EGFR autophosphorylation, resulting in the inhibition of downstream signaling pathways, cell stasis, and/or cell death [31,32]. Since 2009, gefitinib has been a treatment option for locally advanced or metastatic NSCLC with sensitizing mutations of EGFR across all lines of therapy [33]. In July 2015, the FDA approved gefitinib for the first-line treatment of patients with metastatic NSCLC whose tumors harbor EGFR mutations, specifically exon 19 deletions or exon 21 L858R substitution [34]. The recommended dose of gefitinib is $250 \mathrm{mg}$ once per day. Its bioavailability is independent of dose and unaffected by food to any clinically significant extent. After oral administration, gefitinib undergoes rapid blood clearance and has an extensive distribution volume (Table 1) [35]. Although the absolute bioavailability of the recommended dosage of gefitinib in patients is about $50 \%$, the plasma concentration profiles after oral administration have shown that once-daily oral administration of gefitinib is appropriate, with steady-state achieved on day 7 [36]. A higher dose of $500 \mathrm{mg}$ per day has been shown to be more effective but with higher toxicity [37]. The acid dissociation constant of gefitinib is similar to that of erlotinib, at approximately 5.4 [38]. Therefore, its solubility is highly $\mathrm{pH}$-dependent, with a high solubility in the acid range and a solubility significantly lower in near-neutral pH (Table 2) [39].

The significance of the clinical impact of the co-administration of PPIs and H2RAs on gefitinib therapy in NSCLC patients has been extensively studied. The results of the area under the concentration-time curve and the maximum plasma concentration of gefitinib declined to $60 \%$ and $30 \%$, respectively, after pretreatment with a high dose of ranitidine [40]. Kumarakulasinghe et al. and Zenke et al. reported that the concomitant use of PPIs and H2RAs with gefitinib did not significantly impact ORR, PFS, or drug toxicity [41,42]. However, the concentration of gefitinib remained related to its efficacy and the toxicity of the drug $[43,44]$.

Similar to erlotinib, gefitinib is mostly cleared by hepatic metabolism via cytochrome P450 (CYP3A4 and CYP3A5). Gefitinib is mainly excreted as metabolites in the feces with around $90 \%$ of the received dose. The average elimination half-life was $48 \mathrm{~h}$ after administration (50-700 mg/day) in patients with solid tumors [45]. No significant effects of age, sex, bodyweight, or race on the pharmacokinetics of gefitinib have been reported to date. 


\subsection{Afatinib}

Afatinib is the first irreversible oral blocker of the ErbB family. It inhibits the activity of EGFR-1 (ErbB1), EGFR-2 (HER2, ErbB2), and EGFR-4 (HER4, ErbB4), and the transphosphorylation of ErbB3 [22,46]. The U.S. FDA has approved Giotrif for the management of locally advanced or metastatic patients with non-small cell lung cancer with the following characteristics: EGFR del19 or L858R. The approval of afatinib was based on the demonstration of improved PFS in a multicenter, international, open-label, randomized trial, the Lux-Lung 3 trial. Two phase III studies were conducted: Lux-Lung 3 and Lux-Lung 6. The results of the two studies showed an improvement in PFS compared with standard of care chemotherapy, especially in patients with tumors with sensitive EGFR molecular alterations [47]. In the randomized phase IIb Lux-Lung 7 trial, patients who received afatinib had significantly improved PFS and an improved objective response rate compared with those who received gefitinib $(n=159)$ [48]. However, no improvement in overall survival (OS) was shown. A Phase I dose-escalation study was conducted to determine the safety and tolerability of afatinib and the maximum tolerated dose pharmacokinetics. The results show that at a continuous dose of $40 \mathrm{mg} /$ day for 28 days, afatinib was well tolerated and had an acceptable safety profile at the maximum tolerated dose (Table 1) [49,50].

Age, smoking status, and hepatic function have no effect on afatinib exposure. However, patients with low body weight or renal insufficiency are within the range of variability of afatinib exposure. After oral administration, afatinib plasma concentrations are reached for two to five hours and decrease at least bi-exponentially. Unlike other first-generation TKIs, no drug interaction occurs with CYP inducers or CYP inhibitors and acid-suppressant therapy at the approved dose of $40 \mathrm{mg}$ of afatinib (Table 2) [51,52]. However, potent inhibitors or inducers, like rifampicine, probably impact the pharmacokinetics of afatinib [53]. Finally, the recommended dose of afatinib is $40 \mathrm{mg}$ orally once daily; however, the dose can be increased to a maximum of $50 \mathrm{mg} /$ day or decreased to a minimum of $20 \mathrm{mg} /$ day, depending on tolerability $[17,18]$.

\subsection{Osimertinib}

Osimertinib is an orally available, potent, and irreversible inhibitor of EGFR-sensitizing and T790M-resistant molecular alteration [10,54,55]. Osimertinib has high selectivity for EGFR-T790M or EGFR-L858R compared with the wild form. It has demonstrated a high objective response rate in T790M-positive NSCLC patients who progressed on a first-generation EGFR-TKI and had therefore been classified as a breakthrough compound for fast-track development [8]. Today, Osimertinib is approved by the European Union and the United States as a first-line treatment of patients with EGFR-positive metastatic NSCLC and for patients with EGFR T790M-positive metastatic NSCLC after disease progression on an EGFR-TKI [56].

Pharmacokinetic studies of osimertinib have shown that it is slowly absorbed with an absolute bioavailability of 70\% [57]. Osimertinib is orally dispensed at a dose of $80 \mathrm{mg}$ once daily [54] and is quite widely distributed. Osimertinib has a low to moderate clearance for a half-life of approximately 50 to $60 \mathrm{~h}$ in healthy volunteers and approximately $48 \mathrm{~h}$ in patients with metastatic NSCLC (Table 1) [58].

Based on a clinical pharmacokinetic study, food does not alter the bioavailability of osimertinib to a clinically significant extent [59]. A study conducted in healthy volunteers who received $80 \mathrm{mg}$ of osimertinib once daily, and whose gastric $\mathrm{pH}$ was elevated by administration of omeprazole for five days, did not show any impact of this treatment on serum osimertinib concentrations [59]. No changes in the pharmacokinetic profile of osimertinib based on patients' age, sex, body weight, ethnicity, smoking status, or renal impairment have been reported [60,61]. No apparent differences in the safety of osimertinib were observed between patients with normal hepatic function and those with mild or moderate hepatic impairment [62].

Osimertinib exhibits two active metabolites (AZ7550 and AZ5104) that can be detected at approximately $10 \%$ of exposure [58]. Both metabolites appear slowly in plasma after exposure, with a median time of more than $24 \mathrm{~h}$. Osimertinib, AZ5104, and AZ7550 are mainly metabolized by 
CYP3A4 and CYP3A5 through oxidation and dealkylation [63]. CYP, glutathione, and cysteinyl glycine only contribute minimally [64]. Vishwanathan et al. demonstrated that CYP3A4 inhibitors have no clinically significant impact on osimertinib exposure. However, the concomitant exposure of osimertinib with strong CYP3A inducers, such as rifampicin, can significantly decrease osimertinib activity [65]. Therefore, osimertinib has been proposed for concurrent administration with CYP3A inhibitors, but co-administration of strong CYP3A inducers should be avoided with osimertinib if possible (Table 2). If not, the dose should be increased to $160 \mathrm{mg} /$ day. Finally, Harvey et al. assessed the impact of osimertinib on the PK of simvastatin, a sensitive CYP3A substrate, and rosuvastatin, a breast cancer resistance protein (BCRP) substrate, in patients with EGFR mutation-positive NSCLC following progression on an EGFR-TKI. The authors showed that osimertinib had a less than two-fold change inhibitory effect on rosuvastatin exposure and recommended caution when using osimertinib with sensitive BCRP substrates [66].

Recently, Schoenfeld, et al. reported that the sequential combination PD-(L)1 blockade, such as pembrolizumab or durvalumab, and osimertinib was associated with severe immune AEs including pneumonitis and colitis [67]. The authors observed on a cohort of more than 120 patients that AEs appeared were related to a specific drug interaction rather than therapeutic class interaction between osimertinib and PD-1 blockade. Interestingly, toxicity only occurred when anti-PD-(L)1 treatment preceded EGFR-TKIs. In addition, these AEs usually appeared within weeks of starting osimertinib therapy [67]. Although the mechanisms explaining this synergistic toxicity remain unclear, it is possible that EGFR-TKIs differentially improve antigen-specific cytotoxic T-lymphocyte recognition and killing of tumor cells, further validating EGFR inhibitors as immunomodulatory agents that enhance checkpoint blockade [68].

\section{Tolerability Profile of TKIs: Safety and Side Effects}

\subsection{First- and Second-Generation Toxicity}

First- and second-generation EGFR-TKIs are well tolerated. Although AEs are usually minimal, they significantly affect the well-being and quality of life of patients and are therefore often assessed during treatment compliance. TKI side effects are classified by grade according to the National Cancer Institute common terminology criteria for adverse events. TKIs prescription can continue with diarrhea, mucositis, rashes, and paronychia, if well managed. In contrast, severe side effects, such as ocular disorders, interstitial lung disease, severe diarrhea, or severe hepatotoxicity, require immediate discontinuation of treatment. The most common grade 3 or 4 adverse effects reported with these drugs are rash and diarrhea, and less than $10 \%$ of patients discontinue treatment because of AEs (Table 2) [13].

Diarrhea can result from local irritation of the intestine because TKIs are mainly excreted in the stool. The effect of the inhibition of cKit in cells regulating intestinal motility has been proposed [69], which is ranked from grade 1 to 5 according to the frequency and severity of the form. Grade 1 is defined as an increase of less than four stools per day from baseline, grade 2 as 4 to six stools per day from baseline, grade 3 as more than 7 seven stools per day from baseline or incontinence, grade 4 includes life-threatening consequences, and grade 5 is death. The incidence of diarrhea in EGFR-TKI phase III clinical trials has been shown to range from $30 \%$ to around $90 \%$ [70]. Once the other causes of diarrhea have been eliminated (e.g., medication such as laxatives or antibiotics, excess consumption of fiber or diary product, or radiation toxicity [70]), the management of diarrhea induced by EGFR-TKI treatment involves adequate hydration and prescription of anti-diarrheal treatments as usually prescribed for chemotherapy-induced diarrhea; with a low-fiber diet of starchy foods, carrots, and bananas; and avoiding raw fruit and vegetables, dairy products, coffee, and alcohol. Loperamide is an effective therapy to decrease intestinal motility useful for TKI-induced diarrhea. For more severe cases, diphenoxylate and atropine or octreotide has been proposed. TKI treatment is rarely interrupted.

Mucositis has rarely been observed with first-generation TKIs, unlike second-generation TKIs. In the IPASS trial, $0.2 \%$ of patients treated with gefitinib reported grade 3 mucositis/stomatitis [71], 
whereas $8.7 \%$ of patients treated with afatinib in the Lux-Lung 3 experienced grade 3 mucositis/ stomatitis [72]. After an initial assessment of oral health before the start of therapy with an EGFR-TKI, the oral cavity should be evaluated by a health care professional periodically throughout treatment and at treatment completion [73]. Typically, proposed prevention approaches include light but regular brushing with a soft brush, flossing, and saline rinsing. Patients should avoid commercial mouthwashes as they often contain alcohol, as well as alcohol and tobacco products, which can exacerbate the situation [74]. The treatment recommendations of EGFR-TKI-associated mucositis have been proposed by expert consensus and the ESMO guideline [75]. Briefly, oral patients can use a foam swab or a piece of gauze, which are softer and less abrasive, in low mucositis grade. For mild stomatitis, a patient should perform oral care every two to three hours; for patients with moderate-to-severe symptoms, oral care should be performed every one to two hours. Pharmacologic management strategies can be proposed in grade 2 (250-350 mg of erythromycin per day). Treatment for grade 2 stomatitis can also include triamcinolone in dental paste, two to three times daily. For grade 3, clobetasol ointment is used instead of triamcinolone in dental paste, and the erythromycin dose is increased to 500 mg daily [76]. EGFR-TKIs are generally maintained for grades 1 and 2 . They are temporarily stopped for grade 3 until stomatitis or mucositis improves to grade 2 , after which it is resumed at $50 \%$ of the initial dose, then increased if symptoms do not worsen [77].

The most common toxicity of EGFR-targeted agents involves skin structures resulting, most of the time, in early toxicities, including follicular acneiform eruptions, also termed acne-like rashes or folliculitis. The pathogenesis of TKI-induced skin toxicity may involve inflammatory changes within the epidermis as a reaction to the inhibition of intracellular kinase signaling pathways, leading to the modification of proliferation of basal keratinocytes, proinflammatory cytokines, early infiltration of $\mathrm{T}$ lymphocytes, and secondary infections. Skin reaction occurs within one to three weeks after the start of treatment and gradually fades over time. Later toxicities, which are increasingly common with the increasing number of patients treated with the first line in the long-term, occur and correspond to changes in hair texture, sometimes even alopecia, cutaneous xerosis (or skin dryness), and periungual lesions (paronychia and pyogenic granulomas). A rash typically appears within two weeks after starting treatment on the face, shoulders, upper part of the back, or on the chest. The incidence of all grades of rash in phase III clinical trials varies from 37\% to 78\% [78]. This rash is often accompanied by unpleasant sensations, itching, or pain.

The management of folliculitis depends essentially on its severity, the symptoms it causes and its impact on patient quality of life. Therefore, the explanation of the care strategies and symptoms management to the patients is especially important. Tetracyclines can be prescribed as a first-line treatment when an EGFR-TKI is introduced. The management of these complications varies from one team to another. Therapeutic attitudes may include local care at the beginning of treatment or at the time of the rash. Creams and ointments must be applied in sufficient quantities. Exposure to the sun is not recommended. The benefits of cyclic antibiotic therapy are real, and if their effectiveness is insufficient, an adaptation of the treatment should be discussed. A bacteriological sample is taken in cases of possible superinfection, and the patient is referred to a specialized dermatological consultation if necessary. Dose reduction is essential for grade 3, and a grade 4 rash leads to treatment discontinuity.

Beyond the modifications of the matrix and nails, which become fragile, brittle, and whose growth slows down, paronychia and pyogenic granulomas are the nail complications most often observed under EGFR-TKIs. Their incidence varies according to the series. A total of $56 \%$ of patients developed skin AEs in the French study conducted by Osio et al. [79], where only $11 \%$ of patients were treated with afatinib and $4 \%$ with erlotinib in the Lux-Lung 8 study [80]. The incidence of paronychia and pyogenic granulomas increases with the duration of treatment. The management of paronychia is based on local care combined with measures to prevent or limit injuries. If the appearance of the lesion suggests infection, a bacteriological sample is taken. Finally, although the side effects of EGFR-TKIs are often unpleasant, efforts should be made to keep patients on cancer treatment. 


\subsection{Third-Generation Toxicity}

Osimertinib has a good tolerability profile in patients with locally advanced or metastatic EGFR mutation-positive NSCLC. In the dose-escalation cohort of the phase 1 AURA trial, osimertinib exhibited an acceptable safety profile, and no dose-limiting toxicity was reported at any dose tested (ranging from 20-240 mg per day) [81]. In subsequent studies (AURA 2 extension cohort [82], AURA 2 trial [83], AURA 3 trial [10], FLAURA trial [84], and the ASTRIS study [85]), the most common AEs related to osimertinib were rash, diarrhea, nausea, dry skin, paronychia, and stomatitis. Of note, in AURA 1 and 2 trials, four cases of deadly interstitial lung disease occurred that were considered potentially related to osimertinib by the investigators. Fatal adverse events were also reported in the ASTRIS study for four patients in the osimertinib group due to respiratory failure, pneumonitis, and ischemic stroke. Treatment with osimertinib had an acceptable tolerability profile in patients with normal liver function or mild to moderate hepatic impairment and no obvious disparities in safety have been reported to date [62]. Finally, osimertinib is a relatively well-tolerated TKI that appears to have a better toxicity and tolerability profile than the first and second generations.

\section{Applications for Routine EGFR-TKI Dosage}

The current reference analytical method for the measurement of plasmatic EGFR-TKI concentration is liquid chromatography coupled online to tandem mass spectrometry (LC-MS/MS), which combines the advantages of chromatography (high selectivity and separation efficiency) and those of MS (structural information and further increase in selectivity), providing sensitive, specific, and rapid detection of several analytes simultaneously in a single analytical run. Several bioanalytical assays based on LC-MS/MS for the determination of erlotinib and for OSI-420, the active metabolite of erlotinib, in plasma have been reported (Table 3) [19,86-88]. Lankheet, et al. applied this approach for the quantification of erlotinib and $O$-desmethyl erlotinib in plasma and lung tumor tissue samples with an low limit of quantification (LLOQ) of $5.0 \mathrm{ng} / \mathrm{mL}$ and $50 \mathrm{ng} / \mathrm{g}$ in plasma and tumor tissue, respectively, using $50 \mu \mathrm{L}$ of sample [89]. The study of the long-term effect of erlotinib on CYP3A activity was recently assessed in 19 NSCLC patients by analyzing CYP3A activity before and after TKI treatment. The authors observed a two-fold induction in CYP3A activity in patients after two months of erlotinib treatment compared with the activity before the start of the treatment [90]. This result demonstrates the importance of proposing individualized treatment with erlotinib if patients are co-prescribed drugs metabolized by CYP3A during erlotinib treatment. 
Table 3. LC-MS/MS methods for the quantification of the 4 TKI in human plasma.

\begin{tabular}{|c|c|c|c|c|c|c|c|c|c|}
\hline $\begin{array}{l}\text { Generation } \\
\text { Molecule }\end{array}$ & Analyte & IS & $\begin{array}{c}\text { Parent Ion } \\
(\mathrm{m} / \mathrm{z})\end{array}$ & $\begin{array}{l}\text { Product Ion } \\
(\mathrm{m} / \mathrm{z})\end{array}$ & Column & $\begin{array}{l}\text { Calibration Range } \\
\text { (ng/mL) or (nM) }\end{array}$ & $\begin{array}{l}\mathrm{LOQ}(\mathrm{ng} / \mathrm{mL}) \\
\quad \text { or }(\mathrm{nM})\end{array}$ & Extraction & Reference \\
\hline \multirow[t]{7}{*}{$1^{\text {st }}$} & Erlotinib & D8-imatinib & 394.2 & 277.9 & $\mathrm{C} 18(100 \times 2.1 \mathrm{~mm}, 3 \mu \mathrm{m})$ & $50-3500$ & 50 & LLE & [91] \\
\hline & & Elotinib- $-{ }^{13} \mathrm{C}_{6}$ & 394.1 & 278.1 & $\mathrm{C} 18(30 \times 2.1 \mathrm{~mm}, 1.7 \mu \mathrm{m})$ & $5-4000$ & 5 & PP & [92] \\
\hline & & Erlotinib- ${ }^{2} \mathrm{H}_{6}$ & 394.2 & 278.0 & $\mathrm{C} 18(50 \times 2.1 \mathrm{~mm}, 2.6 \mu \mathrm{m})$ & $20-4000$ & 20 & LLE & [93] \\
\hline & & Erlotinib-d6 & 395.2 & 279.2 & $\mathrm{C} 18(100 \times 2.1 \mathrm{~mm}, 1.7 \mu \mathrm{m})$ & $25-5000$ & 25 & PP & [94] \\
\hline & & Erlotinib- ${ }^{13} \mathrm{C}_{6}$ & 394.1 & 278.1 & $\mathrm{C} 18(50 \times 2.1 \mathrm{~mm}, 1.6 \mu \mathrm{m})$ & $25-5000$ & 25 & SPE & [95] \\
\hline & & Omatinib mesylate & 394.0 & 278.3 & $\mathrm{C} 18(50 \times 2.1 \mathrm{~mm}, 3.5 \mu \mathrm{m})$ & $0.01-250 \mathrm{nM}$ & $0.01 \mathrm{nM}$ & LLE & [96] \\
\hline & & Midazolan & 394.2 & 278.0 & $\mathrm{C} 18(150 \times 4.6 \mathrm{~mm}, 5 \mu \mathrm{m})$ & $10-5000$ & 10 & LLE & [87] \\
\hline \multirow[t]{5}{*}{$1^{\text {st }}$} & Gefitinib & Vatalanib & 447.6 & 128.2 & $\mathrm{C} 18(50 \times 2.1 \mathrm{~mm}, 3.5 \mu \mathrm{m})$ & $0.5-1000$ & 0.5 & LLE & [97] \\
\hline & & Gefitinib- ${ }^{2} \mathrm{H}_{8}$ & 447.0 & 128.1 & $\mathrm{C} 18(50 \times 2.1 \mathrm{~mm}, 1.6 \mu \mathrm{m})$ & 4-800 & 4 & SPE & [95] \\
\hline & & Imatinib mesylate & 447.0 & 128.3 & $\mathrm{C} 18(50 \times 2.1 \mathrm{~mm}, 3.5 \mu \mathrm{m})$ & $0.01-100 \mathrm{nM}$ & $0.01 \mathrm{nM}$ & LLE & [96] \\
\hline & & O-methyl gefitinib-d3 & 447.1 & 128.2 & $\mathrm{C} 18(150 \times 2.1 \mathrm{~mm}, 5 \mu \mathrm{m})$ & 5-1000 & 5 & PP & [98] \\
\hline & & Gefitinib-d8 & 447.1 & 128.05 & $\mathrm{C} 18(30 \times 2.1 \mathrm{~mm}, 1.7 \mu \mathrm{m})$ & $2-1600$ & 5 & PP & [92] \\
\hline \multirow[t]{7}{*}{$2^{\text {nd }}$} & Afatinib & Cyclobenzaprine & 486.1 & 276.0 & $\mathrm{C} 18(50 \times 2.0 \mathrm{~mm}, 3 \mu \mathrm{m})$ & $0.5-500$ & 0.5 & LLE & [99] \\
\hline & & Afatinib- $-{ }^{13} \mathrm{C}_{6}$ & 486.2 & 370.9 & $\mathrm{C} 18(50 \times 2.1 \mathrm{~mm}, 2.6 \mu \mathrm{m})$ & $5-250$ & 5 & LLE & [93] \\
\hline & & Cyclobenzaprine & 486.1 & 371.0 & $\mathrm{C} 18(50 \times 2.0 \mathrm{~mm}, 3 \mu \mathrm{m})$ & $5-500$ & 4.3 & LLE & {$[100]$} \\
\hline & & Afatinib-d6 & 486.0 & 112.0 & $\mathrm{C} 18(50 \times 2.1 \mathrm{~mm}, 1.7 \mu \mathrm{m})$ & $1-100$ & 1 & LLE & [101] \\
\hline & & Afatinib- ${ }^{13} \mathrm{C}_{6}$ & 486.1 & 371.0 & $\mathrm{C} 18(50 \times 2.0 \mathrm{~mm}, 5 \mu \mathrm{m})$ & $2-200$ & 2 & LLE & [102] \\
\hline & & Imatinib mesylate & 486.0 & 371.3 & $\mathrm{C} 18(50 \times 2.1 \mathrm{~mm}, 3.5 \mu \mathrm{m})$ & $0.05-100 \mathrm{nM}$ & $0.005 \mathrm{nM}$ & LLE & [96] \\
\hline & & Afatinib- $-{ }^{13} \mathrm{C}_{6}$ & 486.0 & 305.1 & $\mathrm{C} 18(50 \times 2.1 \mathrm{~mm}, 1.6 \mu \mathrm{m})$ & $4-800$ & 4 & SPE & [95] \\
\hline \multirow[t]{4}{*}{$3^{\mathrm{rd}}$} & Osimertinib & Ppazopanib & 500.2 & 72.1 & $\mathrm{C} 18(50 \times 2.1 \mathrm{~mm}, 1.7 \mu \mathrm{m})$ & $1-1000$ & 1 & LLE & [103] \\
\hline & & {$[13 \mathrm{C}, 2 \mathrm{H} 3]$-osimertinib } & 500.1 & 72.1 & $\mathrm{C} 18(50 \times 2.1 \mathrm{~mm}, 2.6 \mu \mathrm{m})$ & $5-1000$ & 5 & LLE & [93] \\
\hline & & Erlotinib-d6 & 500.5 & 72.5 & $\mathrm{C} 18(50 \times 2.1 \mathrm{~mm}, 1.7 \mu \mathrm{m})$ & $10-1000$ & 10 & LLE & [101] \\
\hline & & IS-0741 & 500.4 & 385.3 & $\mathrm{C} 18(50 \times 2.1 \mathrm{~mm}, 1.7 \mu \mathrm{m})$ & $0.5-100$ & 0.5 & PP & [104-106] \\
\hline
\end{tabular}

Abbreviations: IS internal standard, LOQ Limits of quantification, LLE liquid-liquid extraction, SPE solid-phase extraction, PP protein extraction, LC-MS/MS liquid chromatography tandem mass spectrometry. 
Gefetinib quantification has been also largely investigated using LC-MS/MS (Table 3) $[88,98,105-$ 108] (Jones, Stafford et al. 2002, Zhao, He et al. 2003, Guetens, Prenen et al. 2005, Chahbouni, den Burger et al. 2009, Bouchet, Chauzit et al. 2011, Wang, Lim et al. 2011). Gefitinib's metabolites have been poorly investigated. Zheng et al. reported a sensitive, selective, and rapid method for the simultaneous quantification of gefitinib and its major metabolites, but only in mouse plasma [109]. The first validated assay for afatinib quantitation in EDTA plasma, with simultaneous determination of erlotinib and gefitinib, was reported in 2016. The authors developed a specific LC-MS/MS for human and mouse plasma $[92,94]$. More recently, the same group successfully validated a quantitative LC-MS/MS assay for encorafenib (a new generation B-Raf inhibitor), erlotinib, gefitinib, $O$-desmethyl-gefitinib and afatinib in human plasma sing a simple sample pre-treatment procedure and LC-MS/MS [110].

Although LC-MS/MS represents a robust and sensitive quantification technique, it has several shortcomings that have so far prevented its common use in clinical settings for patient monitoring. First, the high initial purchase cost of the instrument and the high maintenance costs are prohibitive for many hospital laboratories. Second, LC-MS/MS is a sophisticated technology that requires highly specialized scientific staff. Finally, the automation of LC-MS/MS systems remains difficult to achieve. Plasma sample preparation and extraction procedures are still conducted manually by laboratory staff, which is slow (usually at least four hours to prepare and analyze a sample) and laborious, especially in routine.

Alternative techniques using LC have been developed to address these concerns, in particular to minimize the analytical run time of gradient elution. Ultra-high-performance liquid chromatography (UHPLC), an ultra-high-pressure system, allows the use of columns with small particles and small diameters, has a faster rate of analysis, a lower solvent consumption (about half), and a positive effect on the efficiency and analysis time [111]. Thus, UHPLC-MS/MS has been assessed for TKI quantification in human plasma samples. Bouchet et al. reported a successful assay quantification of nine TKIs within four minutes of run time using a Waters Acquity-UPLC ${ }^{\circledR}$ system with a BEH C18-50 $\times 2.1 \mathrm{~mm}$ column [105]. Van Erp et al. used an UHPLC Acquity BEH C18 analytical column (100 mm $\times 2.1 \mathrm{~mm} \mathrm{ID,} 1.7 \mu \mathrm{m}$ particle size) coupled to an Acquity TQ tandem MS detector to rapidly quantify six TKIs (imatinib, sunitinib, nilotinib, dasatinib, pazopanib, and regorafenib) and two active metabolites (N-desmethyl imatinib and $\mathrm{N}$-desethyl sunitinib) [112]. Huynh et al. described the analysis of 14 currently used TKIs with an Acquity UPLC BEH C18 $1.7 \mathrm{~mm}(2.1 \times 50 \mathrm{~mm}$; pore size $1.9 \mathrm{~mm})$ analytical column coupled to a tripled quadrupole with an analysis time of five minutes per run [113]. He et al. developed and validated a simple and sensitive UHPLC-MS/MS method for the simultaneous quantification of eight commercial TKIs including erlotinib [114]. Finally, Merienne et al. proposed the quantification of 17 TKIs and two metabolites in human plasma simultaneously, covering a very large panel of TKIs [95].

One of the main advantages of the HPLC-UV assay is its relative high availability in small hospitals laboratories. Since it is important to consider the costs and accessibility of analytical instruments and the possibility of clinicians monitoring TKI concentrations in plasma, this approach could be an alternative methodology. Thus, Faivre et al. were the first to successfully develop a simple, sensitive, and cost-effective HPLC-UV method to simultaneously quantify gefitinib and erlotinib in human plasma from NSCLC patients [115]. The LLOQs found in this study were $20 \mathrm{ng} / \mathrm{mL}$ and $80 \mathrm{ng} / \mathrm{mL}$ for gefitinib and erlotinib, respectively. Recently, Ni et al. successfully developed a hybrid quadrupole-Orbitrap MS (Q-Exactive) method for concurrent determination of several TKIs including erlotinib and gefitinib [116]. The method used in this study offers an attractive LLOQ of $0.05 \mathrm{ng} / \mathrm{mL}$ for erlotinib and gefitinib.

The determination of the concentration of osimertinib in biological samples has been evaluated only recently. Osimertinib could be measured alone or simultaneously with other TKIs by LC-MS/MS [93, $103,104,117,118]$. The results reported contrasting data on osimertinib's stability in plasma. Dickenson et al. showed that osimertinib was very unstable, whereas Rood et al. argued that osimertinib remained stable for a few hours at room temperature [64,103]. This discrepancy needs to be further clarified, as 
the result could have a significant effect on patient sampling. Given the instability of osimertinib at room temperature in plasma and blood, Marijn-Veerman et al. recommend that to minimize osimertinib deprivation, blood and plasma samples should be stored and processed only in ice (at $0{ }^{\circ} \mathrm{C}$ ) [101]. Otherwise, it is not possible to accurately measure osimertinib concentrations as part of therapeutic drug monitoring.

\section{Conclusions and Perspectives}

EGFR-TKIs are currently the standard first-line treatment of patients with advanced NSCLC with activating EGFR mutations. These targeted therapies are usually well tolerated comparative to conventional chemotherapy. The self-oral administration of the drug positively contributes to improving patient compliance and reducing the use of hospital resources [119]. However, this non-invasive route of administration is also associated with unpredictable bioavailability, increased risk of drug interactions, and concerns about patient safety, surveillance, and follow-up. Chronic EGFR-TKIs underdosage may favor the selection of resistant clones and thus disease progression, and overdosage may increase the risk of dose-related side effects. Self-administration also means that the severity of side effects can be considerably impacted by patient behavior (e.g., dietary habits, self-medicating, smoker status). To date, EGFR-TKIs can be administered in advanced NSCLC for a long period of time, usually until the disease progresses or unacceptable toxicity occurs. As early intervention with supportive care strategies can minimize the intensity of adverse reactions or allow for appropriate dose adjustments without the need to discontinue treatment, acute toxicity follow-up and side effect management is of major interest.

Therefore, medical oncologists should not only understand the AEs associated with these drugs, but also develop the necessary skills to detect and treat them to reduce morbidity and mortality as well as premature discontinuation of treatment. Patient education on these strategies is also of major importance and can improve patient tolerance, quality of life, and overall treatment outcome by initiating supportive care soon after symptoms occur. Within this guidance and preventive strategy, the pharmacist can play a major role. Good knowledge of disease monitoring, response milestones, and the risks versus benefits of the treatment options allows pharmacists to better advise patients or counsel patients more effectively. Nurses and prescribers are qualified to monitor toxicity risks as closely as possible. Unfortunately, they do not necessarily do so at regular intervals. Patients can connect with pharmacists who can provide them additional information or complementary recommendations on AEs without the need for patients to rapidly contact prescribers. When more complex or serious AEs appear, pharmacists who work closely with nurses and prescribers can propose the most appropriate therapeutic strategies. Finally, medical oncologists able to understand AEs along with patient education and collaboration between different medical professional groups for therapeutic drug monitoring systems are needed, but further research on the aforementioned methods of relief for continued TKI use should be also performed in the future.

The importance of proactive patient follow-up must be emphasized rather than relying on self-reporting between clinical visits. A randomized trial showed that patients receiving chemotherapy for advanced cancer, web-based symptom reporting with automated clinician e-mail alerts resulted in better health-related quality of life, fewer emergency room visits, fewer hospitalizations, and superior quality-adjusted survival [120].

Recently, Cheema et al. assessed the impact of an interprofessional, proactive follow-up algorithm on the incidence of dose interruptions, reductions, and the severity of AEs in patients on afatinib. The authors reported that over half of first AEs and one third of all grade 1-2 and grade $\geq 3$ AEs were detected through proactive follow-up. This multi-disciplinary AE algorithm resulted in a low rate of costly emergency room or urgent clinic visits and a reduced incidence of severe drug-related AEs and discontinuation therapy.

In conclusion, when closely monitoring patients, the ability of clinicians to make rapid therapeutic decisions in the event of medical complications is critical in the diagnosis and management of 
TKI-related side effects. This is even more decisive in the event of serious or even life-threatening complications. However, good clinician-patient communication, drug patient education, early detection and management of drug side effects, and monitoring of disease response with plasma concentration quantification can also improve patient outcomes. Close cooperation between oncologists, internists, pharmaceutics, and nurses should become the gold standard in the comprehensive clinical care of advanced NSCLC patients receiving TKIs.

Author Contributions: I.S. write the manuscript, F.P. and X.Q. participated to the reviewing of the article.

Funding: This research received no external funding.

Conflicts of Interest: The authors declare no conflict of interest.

\section{References}

1. Hanna, N.; Johnson, D.; Temin, S.; Baker, S., Jr.; Brahmer, J.; Ellis, P.M.; Giaccone, G.; Hesketh, P.J.; Jaiyesimi, I.; Leighl, N.B.; et al. Systemic Therapy for Stage IV Non-Small-Cell Lung Cancer: American Society of Clinical Oncology Clinical Practice Guideline Update. J. Clin. Oncol. 2017, 35, 3484-3515. [CrossRef] [PubMed]

2. Woodcock, J. AstraZeneca Pharmaceuticals LP: Withdrawal of Approval of a New Drug Application for IRESSA. Fed. Regist. 2012, 77, 24723-24724.

3. Astellas Pharma US, I.; Genen-Tech, Inc. Tarceva (erlotinib) Prescribing Information. Available online: www.accessdata.fda.gov/drugsatfda_docs/label/2010/021743s14s16lbl.pdf (accessed on 30 August 2015).

4. Boehringer Ingelheim. Available online: www.accessdata.fda.gov/drugsatfda_docs/label/2013/201292s000lbl. pdf (accessed on 30 August 2015).

5. Rosell, R.; Moran, T.; Carcereny, E.; Quiroga, V.; Molina, M.A.; Costa, C.; Benlloch, S.; Taron, M. Non-small-cell lung cancer harbouring mutations in the EGFR kinase domain. Clin. Transl. Oncol. 2010, 12, 75-80. [CrossRef] [PubMed]

6. Westover, D.; Zugazagoitia, J.; Cho, B.C.; Lovly, C.M.; Paz-Ares, L. Mechanisms of acquired resistance to firstand second-generation EGFR tyrosine kinase inhibitors. Ann. Oncol 2018, 29, i10-i19. [CrossRef]

7. Miller, V.A.; Hirsh, V.; Cadranel, J.; Chen, Y.M.; Park, K.; Kim, S.W.; Zhou, C.; Su, W.C.; Wang, M.; Sun, Y.; et al. Afatinib versus placebo for patients with advanced, metastatic non-small-cell lung cancer after failure of erlotinib, gefitinib, or both, and one or two lines of chemotherapy (LUX-Lung 1): A phase $2 b / 3$ randomised trial. Lancet Oncol. 2012, 13, 528-538. [CrossRef]

8. Katakami, N.; Atagi, S.; Goto, K.; Hida, T.; Horai, T.; Inoue, A.; Ichinose, Y.; Koboyashi, K.; Takeda, K.; Kiura, K.; et al. LUX-Lung 4: A phase II trial of afatinib in patients with advanced non-small-cell lung cancer who progressed during prior treatment with erlotinib, gefitinib, or both. J. Clin. Oncol. 2013, 31, 3335-3341. [CrossRef]

9. AstraZeneca, A.B. Tagrisso-European Medicines Agency-Europa EU. Available online: https://www. ema.europa.eu/en/documents/product-information/tagrisso-epar-product-information_en.pdf (accessed on 1 February 2016).

10. Mok, T.S.; Wu, Y.L.; Ahn, M.J.; Garassino, M.C.; Kim, H.R.; Ramalingam, S.S.; Shepherd, F.A.; He, Y.; Akamatsu, H.; Theelen, W.S.; et al. Osimertinib or Platinum-Pemetrexed in EGFR T790M-Positive Lung Cancer. N. Engl. J. Med. 2017, 376, 629-640. [CrossRef]

11. Soria, J.C.; Ohe, Y.; Vansteenkiste, J.; Reungwetwattana, T.; Chewaskulyong, B.; Lee, K.H.; Dechaphunkul, A.; Imamura, F.; Nogami, N.; Kurata, T.; et al. Osimertinib in Untreated EGFR-Mutated Advanced Non-Small-Cell Lung Cancer. N. Engl. J. Med. 2018, 378, 113-125. [CrossRef]

12. Wang, S.; Song, Y.; Yan, F.; Liu, D. Mechanisms of resistance to third-generation EGFR tyrosine kinase inhibitors. Front. Med. 2016, 10, 383-388. [CrossRef]

13. Ding, P.N.; Lord, S.J.; Gebski, V.; Links, M.; Bray, V.; Gralla, R.J.; Yang, J.C.; Lee, C.K. Risk of Treatment-Related Toxicities from EGFR Tyrosine Kinase Inhibitors: A Meta-analysis of Clinical Trials of Gefitinib, Erlotinib, and Afatinib in Advanced EGFR-Mutated Non-Small Cell Lung Cancer. J. Thorac. Oncol. 2017, 12, 633-643. [CrossRef]

14. Takeda, M.; Okamoto, I.; Tsurutani, J.; Oiso, N.; Kawada, A.; Nakagawa, K. Clinical impact of switching to a second EGFR-TKI after a severe AE related to a first EGFR-TKI in EGFR-mutated NSCLC. Jpn. J. Clin. Oncol. 2012, 42, 528-533. [CrossRef] [PubMed] 
15. Shah, R.R.; Shah, D.R. Safety and Tolerability of Epidermal Growth Factor Receptor (EGFR) Tyrosine Kinase Inhibitors in Oncology. Drug Saf. 2019, 42, 181-198. [CrossRef] [PubMed]

16. Sakata, Y.; Kawamura, K.; Shingu, N.; Hiroshige, S.; Yasuda, Y.; Eguchi, Y.; Anan, K.; Hisanaga, J.; Nitawaki, T.; Nakano, A.; et al. The effects of switching EGFR-TKI treatments for non-small cell lung cancer because of adverse events. Asia Pac. J. Clin. Oncol. 2018. [CrossRef] [PubMed]

17. Li, J.; Zhao, M.; He, P.; Hidalgo, M.; Baker, S.D. Differential metabolism of gefitinib and erlotinib by human cytochrome P450 enzymes. Clin. Cancer Res. 2007, 13, 3731-3737. [CrossRef]

18. Rosell, R.; Carcereny, E.; Gervais, R.; Vergnenegre, A.; Massuti, B.; Felip, E.; Palmero, R.; Garcia-Gomez, R.; Pallares, C.; Sanchez, J.M.; et al. Erlotinib versus standard chemotherapy as first-line treatment for European patients with advanced EGFR mutation-positive non-small-cell lung cancer (EURTAC): A multicentre, open-label, randomised phase 3 trial. Lancet Oncol. 2012, 13, 239-246. [CrossRef]

19. Hidalgo, M.; Siu, L.L.; Nemunaitis, J.; Rizzo, J.; Hammond, L.A.; Takimoto, C.; Eckhardt, S.G.; Tolcher, A.; Britten, C.D.; Denis, L.; et al. Phase I and pharmacologic study of OSI-774, an epidermal growth factor receptor tyrosine kinase inhibitor, in patients with advanced solid malignancies. J. Clin. Oncol. 2001, 19, 3267-3279. [CrossRef]

20. Yamamoto, N.; Horiike, A.; Fujisaka, Y.; Murakami, H.; Shimoyama, T.; Yamada, Y.; Tamura, T. Phase I dose-finding and pharmacokinetic study of the oral epidermal growth factor receptor tyrosine kinase inhibitor Ro50-8231 (erlotinib) in Japanese patients with solid tumors. Cancer Chemother. Pharmacol. 2008, 61, 489-496. [CrossRef]

21. Lu, J.F.; Eppler, S.M.; Wolf, J.; Hamilton, M.; Rakhit, A.; Bruno, R.; Lum, B.L. Clinical pharmacokinetics of erlotinib in patients with solid tumors and exposure-safety relationship in patients with non-small cell lung cancer. Clin. Pharmacol. Ther. 2006, 80, 136-145. [CrossRef]

22. Li, D.; Ambrogio, L.; Shimamura, T.; Kubo, S.; Takahashi, M.; Chirieac, L.R.; Padera, R.F.; Shapiro, G.I.; Baum, A.; Himmelsbach, F.; et al. BIBW2992, an irreversible EGFR/HER2 inhibitor highly effective in preclinical lung cancer models. Oncogene 2008, 27, 4702-4711. [CrossRef]

23. Ling, J.; Johnson, K.A.; Miao, Z.; Rakhit, A.; Pantze, M.P.; Hamilton, M.; Lum, B.L.; Prakash, C. Metabolism and excretion of erlotinib, a small molecule inhibitor of epidermal growth factor receptor tyrosine kinase, in healthy male volunteers. Drug Metab. Dispos. 2006, 34, 420-426. [CrossRef]

24. Kletzl, H.; Giraudon, M.; Ducray, P.S.; Abt, M.; Hamilton, M.; Lum, B.L. Effect of gastric pH on erlotinib pharmacokinetics in healthy individuals: Omeprazole and ranitidine. Anticancer Drugs 2015, 26, 565-572. [CrossRef]

25. Deeken, J.F.; Beumer, J.H.; Anders, N.M.; Wanjiku, T.; Rusnak, M.; Rudek, M.A. Preclinical assessment of the interactions between the antiretroviral drugs, ritonavir and efavirenz, and the tyrosine kinase inhibitor erlotinib. Cancer Chemother. Pharmacol. 2015, 76, 813-819. [CrossRef] [PubMed]

26. Hamilton, M.; Wolf, J.L.; Drolet, D.W.; Fettner, S.H.; Rakhit, A.K.; Witt, K.; Lum, B.L. The effect of rifampicin, a prototypical CYP3A4 inducer, on erlotinib pharmacokinetics in healthy subjects. Cancer Chemother. Pharmacol. 2014, 73, 613-621. [CrossRef] [PubMed]

27. Rakhit, A.; Pantze, M.P.; Fettner, S.; Jones, H.M.; Charoin, J.E.; Riek, M.; Lum, B.L.; Hamilton, M. The effects of CYP3A4 inhibition on erlotinib pharmacokinetics: Computer-based simulation (SimCYP) predicts in vivo metabolic inhibition. Eur J. Clin. Pharmacol. 2008, 64, 31-41. [CrossRef] [PubMed]

28. Rossi, R.E.; Massironi, S.; Conte, D.; Peracchi, M. Therapy for metastatic pancreatic neuroendocrine tumors. Ann. Transl. Med. 2014, 2, 8. [CrossRef] [PubMed]

29. Hamilton, M.; Wolf, J.L.; Rusk, J.; Beard, S.E.; Clark, G.M.; Witt, K.; Cagnoni, P.J. Effects of smoking on the pharmacokinetics of erlotinib. Clin. Cancer Res. 2006, 12, 2166-2171. [CrossRef]

30. Hughes, A.N.; O’Brien, M.E.; Petty, W.J.; Chick, J.B.; Rankin, E.; Woll, P.J.; Dunlop, D.; Nicolson, M.; Boinpally, R.; Wolf, J.; et al. Overcoming CYP1A1/1A2 mediated induction of metabolism by escalating erlotinib dose in current smokers. J. Clin. Oncol. 2009, 27, 1220-1226. [CrossRef]

31. Anderson, N.G.; Ahmad, T.; Chan, K.; Dobson, R.; Bundred, N.J. ZD1839 (Iressa), a novel epidermal growth factor receptor (EGFR) tyrosine kinase inhibitor, potently inhibits the growth of EGFR-positive cancer cell lines with or without erbB2 overexpression. Int. J. Cancer 2001, 94, 774-782. [CrossRef]

32. Ciardiello, F.; Caputo, R.; Bianco, R.; Damiano, V.; Fontanini, G.; Cuccato, S.; De Placido, S.; Bianco, A.R.; Tortora, G. Inhibition of growth factor production and angiogenesis in human cancer cells by ZD1839 (Iressa), a selective epidermal growth factor receptor tyrosine kinase inhibitor. Clin. Cancer Res. 2001, 7, 1459-1465. 
33. Maemondo, M.; Inoue, A.; Kobayashi, K.; Sugawara, S.; Oizumi, S.; Isobe, H.; Gemma, A.; Harada, M.; Yoshizawa, H.; Kinoshita, I.; et al. Gefitinib or chemotherapy for non-small-cell lung cancer with mutated EGFR. N. Engl. J. Med. 2010, 362, 2380-2388. [CrossRef]

34. Douillard, J.Y.; Ostoros, G.; Cobo, M.; Ciuleanu, T.; McCormack, R.; Webster, A.; Milenkova, T. First-line gefitinib in Caucasian EGFR mutation-positive NSCLC patients: A phase-IV, open-label, single-arm study. Br. J. Cancer 2014, 110, 55-62. [CrossRef] [PubMed]

35. Swaisland, H.C.; Smith, R.P.; Laight, A.; Kerr, D.J.; Ranson, M.; Wilder-Smith, C.H.; Duvauchelle, T. Single-dose clinical pharmacokinetic studies of gefitinib. Clin. Pharm. 2005, 44, 1165-1177. [CrossRef] [PubMed]

36. Zhao, C.; Han, S.Y.; Li, P.P. Pharmacokinetics of Gefitinib: Roles of Drug Metabolizing Enzymes and Transporters. Curr. Drug Deliv. 2017, 14, 282-288. [CrossRef] [PubMed]

37. Herbst, R.S.; Maddox, A.M.; Rothenberg, M.L.; Small, E.J.; Rubin, E.H.; Baselga, J.; Rojo, F.; Hong, W.K.; Swaisland, H.; Averbuch, S.D.; et al. Selective oral epidermal growth factor receptor tyrosine kinase inhibitor ZD1839 is generally well-tolerated and has activity in non-small-cell lung cancer and other solid tumors: Results of a phase I trial. J. Clin. Oncol. 2002, 20, 3815-3825. [CrossRef] [PubMed]

38. Smelick, G.S.; Heffron, T.P.; Chu, L.; Dean, B.; West, D.A.; Duvall, S.L.; Lum, B.L.; Budha, N.; Holden, S.N.; Benet, L.Z.; et al. Prevalence of acid-reducing agents (ARA) in cancer populations and ARA drug-drug interaction potential for molecular targeted agents in clinical development. Mol. Pharm. 2013, 10, 4055-4062. [CrossRef] [PubMed]

39. Bergman, E.; Forsell, P.; Persson, E.M.; Knutson, L.; Dickinson, P.; Smith, R.; Swaisland, H.; Farmer, M.R.; Cantarini, M.V.; Lennernas, H. Pharmacokinetics of gefitinib in humans: The influence of gastrointestinal factors. Int. J. Pharm. 2007, 341, 134-142. [CrossRef] [PubMed]

40. Yasumuro, O.; Uchida, S.; Kashiwagura, Y.; Suzuki, A.; Tanaka, S.; Inui, N.; Watanabe, H.; Namiki, N. Changes in gefitinib, erlotinib and osimertinib pharmacokinetics under various gastric $\mathrm{pH}$ levels following oral administration of omeprazole and vonoprazan in rats. Xenobiotica 2018, 48, 1106-1112. [CrossRef]

41. Kumarakulasinghe, N.B.; Syn, N.; Soon, Y.Y.; Asmat, A.; Zheng, H.; Loy, E.Y.; Pang, B.; Soo, R.A. EGFR kinase inhibitors and gastric acid suppressants in EGFR-mutant NSCLC: A retrospective database analysis of potential drug interaction. Oncotarget 2016, 7, 85542-85550. [CrossRef]

42. Zenke, Y.; Yoh, K.; Matsumoto, S.; Umemura, S.; Niho, S.; Ohmatsu, H.; Goto, K.; Ohe, Y. Clinical Impact of Gastric Acid-Suppressing Medication Use on the Efficacy of Erlotinib and Gefitinib in Patients With Advanced Non-Small-Cell Lung Cancer Harboring EGFR Mutations. Clin. Lung Cancer 2016, 17, 412-418. [CrossRef]

43. Zhao, Y.Y.; Li, S.; Zhang, Y.; Zhao, H.Y.; Liao, H.; Guo, Y.; Shi, Y.X.; Jiang, W.; Xue, C.; Zhang, L. The relationship between drug exposure and clinical outcomes of non-small cell lung cancer patients treated with gefitinib. Med. Oncol. 2011, 28, 697-702. [CrossRef]

44. Nakamura, Y.; Sano, K.; Soda, H.; Takatani, H.; Fukuda, M.; Nagashima, S.; Hayashi, T.; Oka, M.; Tsukamoto, K.; Kohno, S. Pharmacokinetics of gefitinib predicts antitumor activity for advanced non-small cell lung cancer. J. Thorac. Oncol. 2010, 5, 1404-1409. [CrossRef] [PubMed]

45. McKillop, D.; Hutchison, M.; Partridge, E.A.; Bushby, N.; Cooper, C.M.; Clarkson-Jones, J.A.; Herron, W.; Swaisland, H.C. Metabolic disposition of gefitinib, an epidermal growth factor receptor tyrosine kinase inhibitor, in rat, dog and man. Xenobiotica 2004, 34, 917-934. [CrossRef] [PubMed]

46. Keating, G.M. Afatinib: A review of its use in the treatment of advanced non-small cell lung cancer. Drugs 2014, 74, 207-221. [CrossRef] [PubMed]

47. Yang, J.C.; Wu, Y.L.; Schuler, M.; Sebastian, M.; Popat, S.; Yamamoto, N.; Zhou, C.; Hu, C.P.; O’Byrne, K.; Feng, J.; et al. Afatinib versus cisplatin-based chemotherapy for EGFR mutation-positive lung adenocarcinoma (LUX-Lung 3 and LUX-Lung 6): Analysis of overall survival data from two randomised, phase 3 trials. Lancet Oncol. 2015, 16, 141-151. [CrossRef]

48. Paz-Ares, L.; Tan, E.H.; O’Byrne, K.; Zhang, L.; Hirsh, V.; Boyer, M.; Yang, J.C.; Mok, T.; Lee, K.H.; Lu, S.; et al. Afatinib versus gefitinib in patients with EGFR mutation-positive advanced non-small-cell lung cancer: Overall survival data from the phase Ilb LUX-Lung 7 trial. Ann. Oncol. 2017, 28, 270-277. [CrossRef]

49. Eskens, F.A.; Mom, C.H.; Planting, A.S.; Gietema, J.A.; Amelsberg, A.; Huisman, H.; van Doorn, L.; Burger, H.; Stopfer, P.; Verweij, J.; et al. A phase I dose escalation study of BIBW 2992, an irreversible dual inhibitor of epidermal growth factor receptor 1 (EGFR) and 2 (HER2) tyrosine kinase in a 2-week on, 2-week off schedule in patients with advanced solid tumours. Br. J. Cancer 2008, 98, 80-85. [CrossRef] 
50. Yap, T.A.; Vidal, L.; Adam, J.; Stephens, P.; Spicer, J.; Shaw, H.; Ang, J.; Temple, G.; Bell, S.; Shahidi, M.; et al. Phase I trial of the irreversible EGFR and HER2 kinase inhibitor BIBW 2992 in patients with advanced solid tumors. J. Clin. Oncol. 2010, 28, 3965-3972. [CrossRef]

51. Gunzer, K.; Joly, F.; Ferrero, J.M.; Gligorov, J.; de Mont-Serrat, H.; Uttenreuther-Fischer, M.; Pelling, K.; Wind, S.; Bousquet, G.; Misset, J.L. A phase II study of afatinib, an irreversible ErbB family blocker, added to letrozole in patients with estrogen receptor-positive hormone-refractory metastatic breast cancer progressing on letrozole. Springerplus 2016, 5, 45. [CrossRef]

52. Suder, A.; Ang, J.E.; Kyle, F.; Harris, D.; Rudman, S.; Kristeleit, R.; Solca, F.; Uttenreuther-Fischer, M.; Pemberton, K.; Pelling, K.; et al. A phase I study of daily afatinib, an irreversible ErbB family blocker, in combination with weekly paclitaxel in patients with advanced solid tumours. Eur. J. Cancer 2015, 51, 2275-2284. [CrossRef]

53. Wind, S.; Giessmann, T.; Jungnik, A.; Brand, T.; Marzin, K.; Bertulis, J.; Hocke, J.; Gansser, D.; Stopfer, P. Pharmacokinetic drug interactions of afatinib with rifampicin and ritonavir. Clin. Drug Investig. 2014, 34, 173-182. [CrossRef]

54. Cross, D.A.; Ashton, S.E.; Ghiorghiu, S.; Eberlein, C.; Nebhan, C.A.; Spitzler, P.J.; Orme, J.P.; Finlay, M.R.; Ward, R.A.; Mellor, M.J.; et al. AZD9291, an irreversible EGFR TKI, overcomes T790M-mediated resistance to EGFR inhibitors in lung cancer. Cancer Discov. 2014, 4, 1046-1061. [CrossRef] [PubMed]

55. Soria, J.C.; Ramalingam, S.S. Osimertinib in EGFR Mutation-Positive Advanced NSCLC. N. Engl. J. Med. 2018, 378, 1262-1263. [CrossRef] [PubMed]

56. Socinski, M.A.; Jotte, R.M.; Cappuzzo, F.; Orlandi, F.; Stroyakovskiy, D.; Nogami, N.; Rodriguez-Abreu, D.; Moro-Sibilot, D.; Thomas, C.A.; Barlesi, F.; et al. Atezolizumab for First-Line Treatment of Metastatic Nonsquamous NSCLC. N. Engl. J. Med. 2018, 378, 2288-2301. [CrossRef] [PubMed]

57. Rossi, A.; Muscarella, L.A.; Di Micco, C.; Carbonelli, C.; D’Alessandro, V.; Notarangelo, S.; Palomba, G.; Sanpaolo, G.; Taurchini, M.; Graziano, P.; et al. Pharmacokinetic drug evaluation of osimertinib for the treatment of non-small cell lung cancer. Expert Opin. Drug Metab. Toxicol. 2017, 13, 1281-1288. [CrossRef]

58. Planchard, D.; Brown, K.H.; Kim, D.W.; Kim, S.W.; Ohe, Y.; Felip, E.; Leese, P.; Cantarini, M.; Vishwanathan, K.; Janne, P.A.; et al. Osimertinib Western and Asian clinical pharmacokinetics in patients and healthy volunteers: Implications for formulation, dose, and dosing frequency in pivotal clinical studies. Cancer Chemother. Pharmacol. 2016, 77, 767-776. [CrossRef]

59. Vishwanathan, K.; Dickinson, P.A.; Bui, K.; Cassier, P.A.; Greystoke, A.; Lisbon, E.; Moreno, V.; So, K.; Thomas, K.; Weilert, D.; et al. The Effect of Food or Omeprazole on the Pharmacokinetics of Osimertinib in Patients With Non-Small-Cell Lung Cancer and in Healthy Volunteers. J. Clin. Pharmacol. 2018, 58, 474-484. [CrossRef]

60. Brown, K.; Comisar, C.; Witjes, H.; Maringwa, J.; de Greef, R.; Vishwanathan, K.; Cantarini, M.; Cox, E. Population pharmacokinetics and exposure-response of osimertinib in patients with non-small cell lung cancer. Br. J. Clin. Pharmacol. 2017, 83, 1216-1226. [CrossRef]

61. Zhang, H. Osimertinib making a breakthrough in lung cancer targeted therapy. Onco Targets Ther. 2016, 9, 5489-5493. [CrossRef]

62. Grande, E.; Harvey, R.D.; You, B.; Batlle, J.F.; Galbraith, H.; Sarantopoulos, J.; Ramalingam, S.S.; Mann, H.; So, K.; Johnson, M.; et al. Pharmacokinetic Study of Osimertinib in Cancer Patients with Mild or Moderate Hepatic Impairment. J. Pharmacol. Exp. Ther. 2019, 369, 291-299. [CrossRef]

63. Ricciuti, B.; Baglivo, S.; Paglialunga, L.; De Giglio, A.; Bellezza, G.; Chiari, R.; Crino, L.; Metro, G. Osimertinib in patients with advanced epidermal growth factor receptor T790M mutation-positive non-small cell lung cancer: Rationale, evidence and place in therapy. Ther. Adv. Med. Oncol. 2017, 9, 387-404. [CrossRef]

64. Dickinson, P.A.; Cantarini, M.V.; Collier, J.; Frewer, P.; Martin, S.; Pickup, K.; Ballard, P. Metabolic Disposition of Osimertinib in Rats, Dogs, and Humans: Insights into a Drug Designed to Bind Covalently to a Cysteine Residue of Epidermal Growth Factor Receptor. Drug Metab. Dispos. 2016, 44, 1201-1212. [CrossRef] [PubMed]

65. Vishwanathan, K.; Dickinson, P.A.; So, K.; Thomas, K.; Chen, Y.M.; De Castro Carpeno, J.; Dingemans, A.C.; Kim, H.R.; Kim, J.H.; Krebs, M.G.; et al. The effect of itraconazole and rifampicin on the pharmacokinetics of osimertinib. Br. J. Clin. Pharmacol. 2018, 84, 1156-1169. [CrossRef] [PubMed]

66. Harvey, R.D.; Aransay, N.R.; Isambert, N.; Lee, J.S.; Arkenau, T.; Vansteenkiste, J.; Dickinson, P.A.; Bui, K.; Weilert, D.; So, K.; et al. Effect of multiple-dose osimertinib on the pharmacokinetics of simvastatin and rosuvastatin. Br. J. Clin. Pharmacol. 2018, 84, 2877-2888. [CrossRef] [PubMed] 
67. Schoenfeld, A.J.; Arbour, K.C.; Rizvi, H.; Iqbal, A.N.; Gadgeel, S.M.; Girshman, J.; Kris, M.G.; Riely, G.J.; Yu, H.A.; Hellmann, M.D. Severe immune-related adverse events are common with sequential PD-(L)1 blockade and osimertinib. Ann. Oncol. 2019, 30, 839-844. [CrossRef]

68. Lizotte, P.H.; Hong, R.L.; Luster, T.A.; Cavanaugh, M.E.; Taus, L.J.; Wang, S.; Dhaneshwar, A.; Mayman, N.; Yang, A.; Kulkarni, M.; et al. A High-Throughput Immune-Oncology Screen Identifies EGFR Inhibitors as Potent Enhancers of Antigen-Specific Cytotoxic T-lymphocyte Tumor Cell Killing. Cancer Immunol. Res. 2018, 6, 1511-1523. [CrossRef]

69. Uribe, J.M.; Gelbmann, C.M.; Traynor-Kaplan, A.E.; Barrett, K.E. Epidermal growth factor inhibits $\mathrm{Ca}\left({ }^{2+}\right)$-dependent $\mathrm{Cl}$ - transport in T84 human colonic epithelial cells. Am. J. Physiol. 1996, 271, C914-C922. [CrossRef]

70. Melosky, B.; Hirsh, V. Management of Common Toxicities in Metastatic NSCLC Related to Anti-Lung Cancer Therapies with EGFR-TKIs. Front. Oncol. 2014, 4, 238. [CrossRef]

71. Mok, T.S.; Wu, Y.L.; Thongprasert, S.; Yang, C.H.; Chu, D.T.; Saijo, N.; Sunpaweravong, P.; Han, B.; Margono, B.; Ichinose, Y.; et al. Gefitinib or carboplatin-paclitaxel in pulmonary adenocarcinoma. N. Engl. J. Med. 2009, 361, 947-957. [CrossRef]

72. Yang, J.C.; Hirsh, V.; Schuler, M.; Yamamoto, N.; O’Byrne, K.J.; Mok, T.S.; Zazulina, V.; Shahidi, M.; Lungershausen, J.; Massey, D.; et al. Symptom control and quality of life in LUX-Lung 3: A phase III study of afatinib or cisplatin/pemetrexed in patients with advanced lung adenocarcinoma with EGFR mutations. J. Clin. Oncol. 2013, 31, 3342-3350. [CrossRef]

73. Lacouture, M.E.; Anadkat, M.J.; Bensadoun, R.J.; Bryce, J.; Chan, A.; Epstein, J.B.; Eaby-Sandy, B.; Murphy, B.A.; Group, M.S.T.S. Clinical practice guidelines for the prevention and treatment of EGFR inhibitor-associated dermatologic toxicities. Support. Care Cancer 2011, 19, 1079-1095. [CrossRef]

74. Lalla, R.V.; Bowen, J.; Barasch, A.; Elting, L.; Epstein, J.; Keefe, D.M.; McGuire, D.B.; Migliorati, C.; Nicolatou-Galitis, O.; Peterson, D.E.; et al. MASCC/ISOO clinical practice guidelines for the management of mucositis secondary to cancer therapy. Cancer 2014, 120, 1453-1461. [CrossRef] [PubMed]

75. Peterson, D.E.; Boers-Doets, C.B.; Bensadoun, R.J.; Herrstedt, J.; Committee, E.G. Management of oral and gastrointestinal mucosal injury: ESMO Clinical Practice Guidelines for diagnosis, treatment, and follow-up. Ann. Oncol. 2015, 26 (Suppl. 5), v139-v151. [CrossRef]

76. Melosky, B.; Leighl, N.B.; Rothenstein, J.; Sangha, R.; Stewart, D.; Papp, K. Management of egfr tki-induced dermatologic adverse events. Curr. Oncol. 2015, 22, 123-132. [CrossRef] [PubMed]

77. Kato, S.; Saito, A.; Matsuda, N.; Suzuki, H.; Ujiie, M.; Sato, S.; Miyazaki, K.; Kodama, T.; Satoh, H. Management of afatinib-induced stomatitis. Mol. Clin. Oncol. 2017, 6, 603-605. [CrossRef] [PubMed]

78. Hirsh, V. Managing treatment-related adverse events associated with egfr tyrosine kinase inhibitors in advanced non-small-cell lung cancer. Curr. Oncol. 2011, 18, 126-138. [CrossRef]

79. Osio, A.; Mateus, C.; Soria, J.C.; Massard, C.; Malka, D.; Boige, V.; Besse, B.; Robert, C. Cutaneous side-effects in patients on long-term treatment with epidermal growth factor receptor inhibitors. Br. J. Dermatol. 2009, 161, 515-521. [CrossRef]

80. Felip, E.; Hirsh, V.; Popat, S.; Cobo, M.; Fulop, A.; Dayen, C.; Trigo, J.M.; Gregg, R.; Waller, C.F.; Soria, J.C.; et al. Symptom and Quality of Life Improvement in LUX-Lung 8, an Open-Label Phase III Study of Second-Line Afatinib Versus Erlotinib in Patients With Advanced Squamous Cell Carcinoma of the Lung After First-Line Platinum-Based Chemotherapy. Clin. Lung Cancer 2018, 19, 74-83. [CrossRef]

81. Janne, P.A.; Yang, J.C.; Kim, D.W.; Planchard, D.; Ohe, Y.; Ramalingam, S.S.; Ahn, M.J.; Kim, S.W.; Su, W.C.; Horn, L.; et al. AZD9291 in EGFR inhibitor-resistant non-small-cell lung cancer. N. Engl. J. Med. 2015, 372, 1689-1699. [CrossRef]

82. Yang, J.C.; Ahn, M.J.; Kim, D.W.; Ramalingam, S.S.; Sequist, L.V.; Su, W.C.; Kim, S.W.; Kim, J.H.; Planchard, D.; Felip, E.; et al. Osimertinib in Pretreated T790M-Positive Advanced Non-Small-Cell Lung Cancer: AURA Study Phase II Extension Component. J. Clin. Oncol. 2017, 35, 1288-1296. [CrossRef]

83. Goss, G.; Tsai, C.M.; Shepherd, F.A.; Bazhenova, L.; Lee, J.S.; Chang, G.C.; Crino, L.; Satouchi, M.; Chu, Q.; Hida, T.; et al. Osimertinib for pretreated EGFR Thr790Met-positive advanced non-small-cell lung cancer (AURA2): A multicentre, open-label, single-arm, phase 2 study. Lancet Oncol. 2016, 17, 1643-1652. [CrossRef] 
84. Cho, B.C.; Chewaskulyong, B.; Lee, K.H.; Dechaphunkul, A.; Sriuranpong, V.; Imamura, F.; Nogami, N.; Kurata, T.; Okamoto, I.; Zhou, C.; et al. Osimertinib versus Standard of Care EGFR TKI as First-Line Treatment in Patients with EGFRm Advanced NSCLC: FLAURA Asian Subset. J. Thorac. Oncol. 2019, 14, 99-106. [CrossRef] [PubMed]

85. de Marinis, F.; Wu, Y.L.; de Castro, G., Jr.; Chang, G.C.; Chen, Y.M.; Cho, B.C.; Freitas, H.C.; Jiang, L.; Kim, S.W.; Martin, C.; et al. ASTRIS: A global real-world study of osimertinib in $>3000$ patients with EGFR T790M positive non-small-cell lung cancer. Future Oncol. 2019, 15, 3003-3014. [CrossRef] [PubMed]

86. Lepper, E.R.; Swain, S.M.; Tan, A.R.; Figg, W.D.; Sparreboom, A. Liquid-chromatographic determination of erlotinib (OSI-774), an epidermal growth factor receptor tyrosine kinase inhibitor. J. Chromatogr. B Anal. Technol. Biomed. Life Sci. 2003, 796, 181-188. [CrossRef]

87. Masters, A.R.; Sweeney, C.J.; Jones, D.R. The quantification of erlotinib (OSI-774) and OSI-420 in human plasma by liquid chromatography-tandem mass spectrometry. J. Chromatogr. B Anal. Technol. Biomed. Life Sci. 2007, 848, 379-383. [CrossRef] [PubMed]

88. Zhao, M.; He, P.; Rudek, M.A.; Hidalgo, M.; Baker, S.D. Specific method for determination of OSI-774 and its metabolite OSI-420 in human plasma by using liquid chromatography-tandem mass spectrometry. J. Chromatogr. B Anal. Technol. Biomed. Life Sci. 2003, 793, 413-420. [CrossRef]

89. Lankheet, N.A.; Schaake, E.E.; Rosing, H.; Burgers, J.A.; Schellens, J.H.; Beijnen, J.H.; Huitema, A.D. Quantitative determination of erlotinib and O-desmethyl erlotinib in human EDTA plasma and lung tumor tissue. Bioanalysis 2012, 4, 2563-2577. [CrossRef]

90. Svedberg, A.; Vikingsson, S.; Vikstrom, A.; Hornstra, N.; Kentson, M.; Branden, E.; Koyi, H.; Bergman, B.; Green, H. Erlotinib treatment induces cytochrome P450 3A activity in non-small cell lung cancer patients. Br. J. Clin. Pharmacol. 2019, 85, 1704-1709. [CrossRef]

91. Andriamanana, I.; Gana, I.; Duretz, B.; Hulin, A. Simultaneous analysis of anticancer agents bortezomib, imatinib, nilotinib, dasatinib, erlotinib, lapatinib, sorafenib, sunitinib and vandetanib in human plasma using LC/MS/MS. J. Chromatogr. B Anal. Technol. Biomed. Life Sci. 2013, 926, 83-91. [CrossRef]

92. Sparidans, R.W.; van Hoppe, S.; Rood, J.J.; Schinkel, A.H.; Schellens, J.H.; Beijnen, J.H. Liquid chromatography-tandem mass spectrometric assay for the tyrosine kinase inhibitor afatinib in mouse plasma using salting-out liquid-liquid extraction. J. Chromatogr. B Anal. Technol. Biomed. Life Sci. 2016, 1012, 118-123. [CrossRef]

93. Reis, R.; Labat, L.; Allard, M.; Boudou-Rouquette, P.; Chapron, J.; Bellesoeur, A.; Thomas-Schoemann, A.; Arrondeau, J.; Giraud, F.; Alexandre, J.; et al. Liquid chromatography-tandem mass spectrometric assay for therapeutic drug monitoring of the EGFR inhibitors afatinib, erlotinib and osimertinib, the ALK inhibitor crizotinib and the VEGFR inhibitor nintedanib in human plasma from non-small cell lung cancer patients. J. Pharm. Biomed. Anal. 2018, 158, 174-183. [CrossRef]

94. Svedberg, A.; Green, H.; Vikstrom, A.; Lundeberg, J.; Vikingsson, S. A validated liquid chromatography tandem mass spectrometry method for quantification of erlotinib, OSI-420 and didesmethyl erlotinib and semi-quantification of erlotinib metabolites in human plasma. J. Pharm. Biomed. Anal. 2015, 107, 186-195. [CrossRef] [PubMed]

95. Merienne, C.; Rousset, M.; Ducint, D.; Castaing, N.; Titier, K.; Molimard, M.; Bouchet, S. High throughput routine determination of 17 tyrosine kinase inhibitors by LC-MS/MS. J. Pharm. Biomed. Anal. 2018, 150, 112-120. [CrossRef] [PubMed]

96. Hayashi, H.; Kita, Y.; Iihara, H.; Yanase, K.; Ohno, Y.; Hirose, C.; Yamada, M.; Todoroki, K.; Kitaichi, K.; Minatoguchi, S.; et al. Simultaneous and rapid determination of gefitinib, erlotinib and afatinib plasma levels using liquid chromatography/tandem mass spectrometry in patients with non-small-cell lung cancer. Biomed. Chromatogr. 2016, 30, 1150-1154. [CrossRef] [PubMed]

97. Guan, S.; Chen, X.; Wang, F.; Xin, S.; Feng, W.; Zhu, X.; Liu, S.; Zhuang, W.; Zhou, S.; Huang, M.; et al. Development and validation of a sensitive LC-MS/MS method for determination of gefitinib and its major metabolites in human plasma and its application in non-small cell lung cancer patients. J. Pharm. Biomed. Anal. 2019, 172, 364-371. [CrossRef]

98. Wang, L.Z.; Lim, M.Y.; Chin, T.M.; Thuya, W.L.; Nye, P.L.; Wong, A.; Chan, S.Y.; Goh, B.C.; Ho, P.C. Rapid determination of gefitinib and its main metabolite, O-desmethyl gefitinib in human plasma using liquid chromatography-tandem mass spectrometry. J. Chromatogr. B Anal. Technol. Biomed. Life Sci. 2011, 879, 2155-2161. [CrossRef] 
99. Kadi, A.A.; Abdelhameed, A.S.; Darwish, H.W.; Attwa, M.W.; Al-Shakliah, N.S. A highly efficient and sensitive LC-MS/MS method for the determination of afatinib in human plasma: Application to a metabolic stability study. Biomed. Chromatogr. 2016, 30, 1248-1255. [CrossRef]

100. Abdelhameed, A.S.; Attwa, M.W.; Kadi, A.A. An LC-MS/MS method for rapid and sensitive high-throughput simultaneous determination of various protein kinase inhibitors in human plasma. Biomed. Chromatogr. 2017, 31, e3793. [CrossRef]

101. Veerman, G.D.M.; Lam, M.H.; Mathijssen, R.H.J.; Koolen, S.L.W.; de Bruijn, P. Quantification of afatinib, alectinib, crizotinib and osimertinib in human plasma by liquid chromatography/triple-quadrupole mass spectrometry; focusing on the stability of osimertinib. J. Chromatogr. B Anal. Technol. Biomed. Life Sci. 2019, 1113, 37-44. [CrossRef]

102. Herbrink, M.; de Vries, N.; Rosing, H.; Huitema, A.D.R.; Nuijen, B.; Schellens, J.H.M.; Beijnen, J.H. Development and validation of a liquid chromatography-tandem mass spectrometry analytical method for the therapeutic drug monitoring of eight novel anticancer drugs. Biomed. Chromatogr. 2018, 32. [CrossRef]

103. Rood, J.J.M.; van Bussel, M.T.J.; Schellens, J.H.M.; Beijnen, J.H.; Sparidans, R.W. Liquid chromatographytandem mass spectrometric assay for the T790M mutant EGFR inhibitor osimertinib (AZD9291) in human plasma. J. Chromatogr. B Anal. Technol. Biomed. Life Sci. 2016, 1031, 80-85. [CrossRef]

104. Zheng, X.; Wang, W.; Zhang, Y.; Ma, Y.; Zhao, H.; Hu, P.; Jiang, J. Development and validation of a UPLC-MS/MS method for quantification of osimertinib (AZD9291) and its metabolite AZ5104 in human plasma. Biomed. Chromatogr. 2018, 32, e4365. [CrossRef] [PubMed]

105. Bouchet, S.; Chauzit, E.; Ducint, D.; Castaing, N.; Canal-Raffin, M.; Moore, N.; Titier, K.; Molimard, M. Simultaneous determination of nine tyrosine kinase inhibitors by 96 -well solid-phase extraction and ultra performance LC/MS-MS. Clin. Chim. Acta 2011, 412, 1060-1067. [CrossRef] [PubMed]

106. Chahbouni, A.; den Burger, J.C.; Vos, R.M.; Sinjewel, A.; Wilhelm, A.J. Simultaneous quantification of erlotinib, gefitinib, and imatinib in human plasma by liquid chromatography tandem mass spectrometry. Ther. Drug Monit. 2009, 31, 683-687. [CrossRef] [PubMed]

107. Guetens, G.; Prenen, H.; De Boeck, G.; Van Dongen, W.; Esmans, E.; Lemiere, F.; van Oosterom, A.T.; Schoffski, P.; de Bruijn, E.A. Sensitive and specific quantification of the anticancer agent ZD1839 (Gefitinib) in plasma by on-column focusing capillary liquid chromatography-tandem mass spectrometry. J. Chromatogr. A 2005, 1082, 2-5. [CrossRef]

108. Jones, H.K.; Stafford, L.E.; Swaisland, H.C.; Payne, R. A sensitive assay for ZD1839 (Iressa) in human plasma by liquid-liquid extraction and high performance liquid chromatography with mass spectrometric detection: Validation and use in Phase I clinical trials. J. Pharm. Biomed. Anal. 2002, 29, 221-228. [CrossRef]

109. Zheng, N.; Zhao, C.; He, X.R.; Jiang, S.T.; Han, S.Y.; Xu, G.B.; Li, P.P. Simultaneous determination of gefitinib and its major metabolites in mouse plasma by HPLC-MS/MS and its application to a pharmacokinetics study. J. Chromatogr. B Anal. Technol. Biomed. Life Sci. 2016, 1011, 215-222. [CrossRef]

110. Sparidans, R.W.; Rosing, H.; Rood, J.J.M.; Schellens, J.H.M.; Beijnen, J.H. Liquid chromatography-tandem mass spectrometric assay for therapeutic drug monitoring of the B-Raf inhibitor encorafenib, the EGFR inhibitors afatinib, erlotinib and gefitinib and the $O$-desmethyl metabolites of erlotinib and gefitinib in human plasma. J. Chromatogr. B Anal. Technol. Biomed. Life Sci. 2016, 1033, 390-398. [CrossRef]

111. Cakir, O.; Arslan, A.; Inan, N.; Anik, Y.; Sarisoy, T.; Gumustas, S.; Akansel, G. Comparison of the diagnostic performances of diffusion parameters in diffusion weighted imaging and diffusion tensor imaging of breast lesions. Eur. J. Radiol. 2013, 82, e801-e806. [CrossRef]

112. van Erp, N.P.; de Wit, D.; Guchelaar, H.J.; Gelderblom, H.; Hessing, T.J.; Hartigh, J. A validated assay for the simultaneous quantification of six tyrosine kinase inhibitors and two active metabolites in human serum using liquid chromatography coupled with tandem mass spectrometry. J. Chromatogr. B Anal. Technol. Biomed. Life Sci. 2013, 937, 33-43. [CrossRef]

113. Huynh, H.H.; Pressiat, C.; Sauvageon, H.; Madelaine, I.; Maslanka, P.; Lebbe, C.; Thieblemont, C.; Goldwirt, L.; Mourah, S. Development and Validation of a Simultaneous Quantification Method of 14 Tyrosine Kinase Inhibitors in Human Plasma Using LC-MS/MS. Ther. Drug Monit. 2017, 39, 43-54. [CrossRef]

114. He, Y.; Zhou, L.; Gao, S.; Yin, T.; Tu, Y.; Rayford, R.; Wang, X.; Hu, M. Development and validation of a sensitive LC-MS/MS method for simultaneous determination of eight tyrosine kinase inhibitors and its application in mice pharmacokinetic studies. J. Pharm. Biomed. Anal. 2018, 148, 65-72. [CrossRef] [PubMed] 
115. Faivre, L.; Gomo, C.; Mir, O.; Taieb, F.; Schoemann-Thomas, A.; Ropert, S.; Vidal, M.; Dusser, D.; Dauphin, A.; Goldwasser, F.; et al. A simple HPLC-UV method for the simultaneous quantification of gefitinib and erlotinib in human plasma. J. Chromatogr. B Anal. Technol. Biomed. Life Sci. 2011, 879, 2345-2350. [CrossRef] [PubMed]

116. Ni, M.W.; Zhou, J.; Li, H.; Chen, W.; Mou, H.Z.; Zheng, Z.G. Simultaneous determination of six tyrosine kinase inhibitors in human plasma using HPLC-Q-Orbitrap mass spectrometry. Bioanalysis 2017, 9, 925-935. [CrossRef] [PubMed]

117. Xiong, S.; Deng, Z.; Sun, P.; Mu, Y.; Xue, M. Development and Validation of a Rapid and Sensitive LC-MS/MS Method for the Pharmacokinetic Study of Osimertinib in Rats. J. AOAC Int. 2017, 100, 1771-1775. [CrossRef] [PubMed]

118. Dong, S.T.; Li, Y.; Yang, H.T.; Wu, Y.; Li, Y.J.; Ding, C.Y.; Meng, L.; Dong, Z.J.; Zhang, Y. An Accurate and Effective Method for Measuring Osimertinib by UPLC-TOF-MS and Its Pharmacokinetic Study in Rats. Molecules 2018, 23, 2894. [CrossRef]

119. Jin, J.; Sklar, G.E.; Min Sen Oh, V.; Chuen Li, S. Factors affecting therapeutic compliance: A review from the patient's perspective. Ther. Clin. Risk Manag. 2008, 4, 269-286. [CrossRef]

120. Basch, E.; Deal, A.M.; Kris, M.G.; Scher, H.I.; Hudis, C.A.; Sabbatini, P.; Rogak, L.; Bennett, A.V.; Dueck, A.C.; Atkinson, T.M.; et al. Symptom Monitoring With Patient-Reported Outcomes During Routine Cancer Treatment: A Randomized Controlled Trial. J. Clin. Oncol. 2016, 34, 557-565. [CrossRef]

(C) 2019 by the authors. Licensee MDPI, Basel, Switzerland. This article is an open access article distributed under the terms and conditions of the Creative Commons Attribution (CC BY) license (http://creativecommons.org/licenses/by/4.0/). 